\title{
Desire and Passion Ride to War (Unknown Artist)
}

\section{SELECTOR'S NOTE}

This sculptured pair of the Hindu god of love, Manmatha (or Kamadeva), and his wife, Rati (Desire), is from the Varadaraja temple in Kanchipuram, one of the most important temples dedicated to the god Vishnu in the far south of India. These two lovers adorn the marriage hall where wedding ceremonies for the temple's main deity, Vishnu the King among Boon-Givers (Varadaraja, who lends the temple its name), and his consort, the goddess of wealth, are held as part of annual festivals; marriage halls are a feature of Hindu temples built during the Vijayanagaram period between the fourteenth and sixteenth centuries. The marriage hall of the Varadaraja temple is one of the major repositories of the refined sixteenth-century sculptural style in the Tamil country of south India. I like this sculptured pair because of their boldness, scale, and fierce movement. 


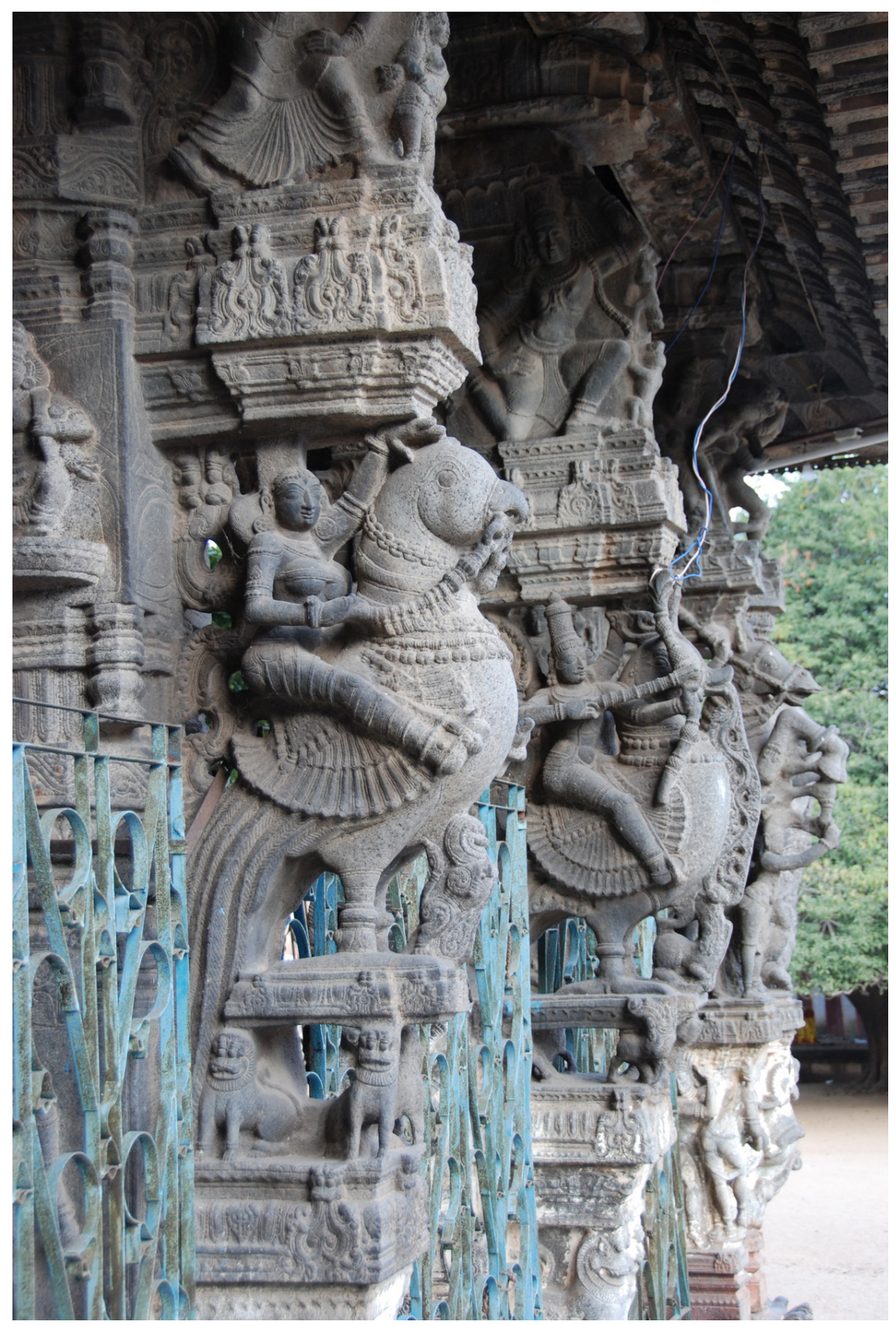

FIGURE 1. Rati and Manmatha panel. Photo courtesy of Brigitte Majlis. 


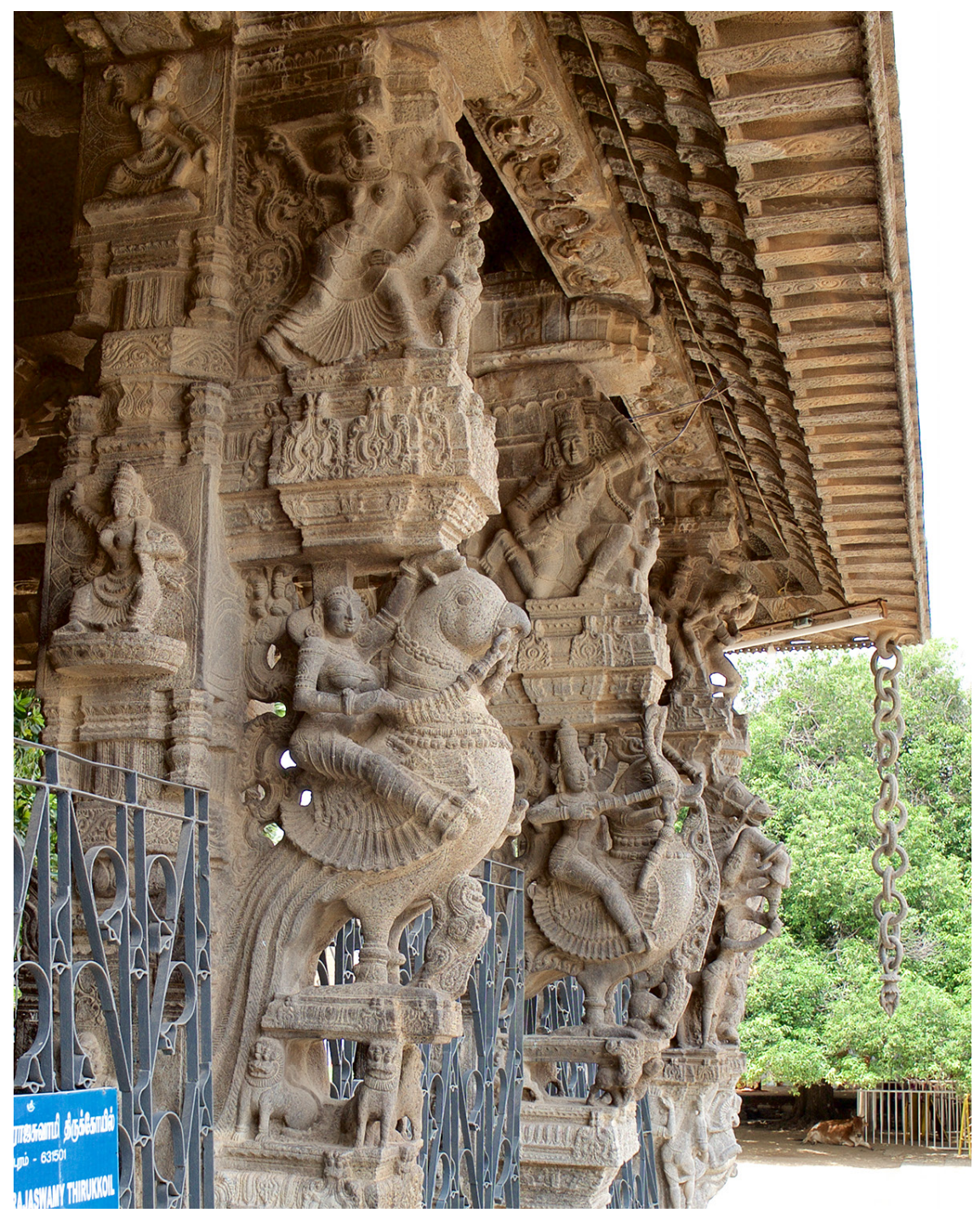

FIGURE 2. Rati and Manmatha panel. Photo courtesy of Anna Lise Seastrand. 


\section{PILLARS OF LOVE: A DIALOGIC READING \\ OF TEMPLE SCULPTURE}

\section{Anna Lise Seastrand (Near Reader)}

This short essay takes inspiration from anubhava, a Sanskrit word meaning perception, apprehension, or understanding that occurs through aesthetic experience. It is the word that describes the experience of divine love and enjoyment, and is particularly associated with praise of the god Vishnu in the tradition of Tamil devotional poetry in southeastern India. These ideas are particularly apt for a close reading of the imagery at the Varadaraja temple complex in the city of Kanchipuram, which culminates in the relationship between a pair of sculptural pillars joined together as a dynamic, oppositional couple within the Kalyana Mandapa, a hall of auspicious union that celebrates divine beauty and love.

Kanchipuram, in the far southeast corner of India, is an ancient city crowded with hundreds of temples and royal foundations. It is a beautiful city, situated along the Palar River, which flows out to the Bay of Bengal, some forty-five miles downstream. It is lush with palm trees, fields of bright green paddy, and numerous ponds and lakes. Kanchipuram has long been a cosmopolitan center, a point of contact for traders, scholars, and pilgrims: in the seventh century, the Chinese Buddhist pilgrim Xuanzang reported visiting the court of King Narasimha Pallava and finding more than one hundred Buddhist monasteries and thousands of monks in the region. Buddhists lived alongside others who worshiped Shiva, Vishnu, the Jina, and the Goddess, among other lesser-known deities. The temples built to worship these gods were famed far and wide, as were the luminous silk and gold fabrics woven to adorn them.

Situated in the southeast part of the city on a small hillock is the temple of Varadaraja Perumal, a form of Vishnu. Here he is joined by Perundevi Tayar, a form of the Lakshmi, the Hindu goddess of wealth, fortune, and prosperity. In every south Indian Hindu temple, the god and goddess are at once their distinct individual selves, particular to the place they inhabit, and at the same time universal deities that transcend their local manifestations. There are innumerable forms that Vishnu takes in different times and places. Here he is Varadaraja, the King among Boon-Givers. His temple is ancient but still young: ritually renewed, renovated, and expanded for more than a thousand years.

Today's pilgrims - whether pursuing art or devotion-enter into the temple from the western gateway tower, or gopura, which rises eight stories to a height of 160 feet, towering over the temple compound's roughly twenty acres enclosed within high walls. Stepping through the massive structure, the visitor enters into a huge open courtyard. Straight ahead, across the courtyard, is another monumental gateway that leads into the enclosed space of the temple's shrines. But to the left, within the grand expanse of the courtyard, is an open structure, striking for the massive granite-carved figures, warlike horses, and gods and goddesses that extend 
from the surface of raised foundation and pillars that support the deep eaves and curling roof, in the absence of enclosing walls. The glinting sun, reflected by the temple's pond beyond, illuminates this monumental building from the north. This radiant space is the marriage festival hall (kalyāna-mandapa).

The hall is approached from the south-but even before entering, the attentive viewer is rewarded with a show of sculptural virtuosity. Along the roofline, stone cats stalk stone pigeons; long open-work chains carved from a single piece of granite hang under graceful ornaments at the roof's corners (see fig. 2). Under the deep eaves are carefully sculpted beams, a trompe l'oeil that imitates wooden architecture. Across the front of the building are eight monolithic pillars, four on each side of the center stairway; each features a mounted rider who emerges from the stone at one-third life-size. Walking up the stairs and into this pillared hall, the pilgrim is met by spear- and sword-wielding warriors mounted on rearing horses on both sides of the processional path to the central dais. These rearing animals and riders, caught in mid-action, threaten to emerge from their architectural matrix, so fully are they sculpted in the round. When Vishnu and Lakshmi are present, seated on the raised central platform, these imposing and lifelike figures augment the living presence of the deities.

The dais at the center of the hall is situated on the back of a tortoise, whose shell, legs, and head spread out from under the gods' seat. Cosmologically, the tortoise is the support of the all that is. Separately carved images of demigods are fit into sockets around the base of the dais: traditional temple architecture uses no mortar; instead, all the stone pieces interlock with one another. This architectural feat is even more impressive in the ornate lantern-dome ceiling above, from which an elaborate pendant lotus extends down toward the deities when they are seated during festivals. Altogether, this central space of the hall is a microcosm, where the gods rest above the tortoise, who holds the world aloft, beneath the rising heavens crowned by the pendant lotus that points back to the deities seated below. During the festival of their wedding, the gods are the center of this cosmic scheme, surrounded by the ninety-six monolithic pillars whose sculptural figures situate the gods within the context of their devotees' lives. This is a building literally inseparable from its decorative program, which celebrates kalyanna-good fortune, prosperity, virtue, joyful celebration, and marriage.

The sculptures invite their viewers into limited communion: a tiger pounces on a rider; an entertainer's disfigurement attracts and repels; dancers make festive a now-silent space. Among the most captivating figures are two pairs of the god and goddess of love, Manmatha and Rati, facing out on the massive pillars on both sides of the hall's southern entrance (see fig. 1). The god of love, Manmatha, seated on his gander, and the goddess of desire, Rati, astride her parrot, ride toward the visitor who approaches the marriage hall, a reminder that this is a space of erotic and auspicious union. 
Manmatha means love or desire; he is also known as the love god Kama. Rati is desire, longing, and even coition. Manmatha and Rati, Love and Desire, are paired between guardian figures at the front of the building on both the east and west sides. Like the guardian figures, they too are dressed for battle, carrying sugarcane bows and lotus-stalk arrows. Love is, they seem to say, a battlefield. Indeed, the intersubjectivity of love is like that of combat: both are intimate, exhilarating, and potentially devastating. The piercing arrow of desire, like that of battle, abolishes the distance between the self and the other. The dynamic exchange between the lithic manifestations of Manmatha and Rati suggests just such a union. Their coupling is expressed in the paired oppositions in and between Love and Desire's columns: inside and outside, male and female, individual and pair, play and war. The longed-for union of Love and Desire is expressed across the physical space that separates them; the conjugation of figural sculptures that face each other across the two columns enlivens the space between them.

To read these sculptures' figures with sensitivity to their disposition and regard toward one another requires that the viewer linger over their forms, counting each detail as an important part of the whole. Indeed, the sensitivity required of the viewer is like that of the lover who knows intimately each part that makes the whole of his or her beloved, the shades of meaning betrayed by a glance or the shape of the body. This kind of loving, careful description of the form of the beloved is a trope that crosses languages and genres of Indic literature. To read the sculptures is to share in an aesthetics of participatory enjoyment and experience-anubhava. To read them closely is to savor them as one savors the beloved-a mode of description and devotion closely identified with southeast Indian devotional literature that identifies the beloved as God himself. Devotional poetry in praise of Vishnu draws extensively on tropes of erotic and filial love, as well as visions of martial victory. War, death, love, and union are the extraordinary contexts for the most intimate and transformative acts of human life and intersubjectivity. Perhaps it is precisely the intimacy and transformative possibility that draw both love and war into the heart of the expression of religious experience.

The following description portrays the relationship between each pair of figures, from the top of the columns to the base, to which the mounted figures of Manmatha and Rati are attached, though the columns are not visible in this image. Those on the east face of Rati's pillar are paired with those on the west of Manmatha's.

On the east side of the capital above the figure of Rati (invisible from the eastward-looking perspective of figs. 1 and 2) a female musician holds a veena, an instrument associated with the goddess Sarasvati, patron of learning and knowledge. The veena player faces a male dancer, visible on the capital of Manmatha's column. The figures' bodies each mirror the other's pose. They are mutually attuned-in tune, yet different, poised in counterpoint, in dance and music, facing each other across the space of the columns' distance. 
Just below the capital, and inside, at the top of the column to which Rati is attached, a woman speaks to a parrot she holds in her left hand. Parrots are strongly associated with love, and in literature they often serve as messengers between lovers. Parrots are able to repeat what they hear, and as witnesses to lovemaking, also have the capacity to embarrass the lovers or to reignite their passions upon hearing the parrot's repetition. Here, the woman whispers into the ear of her avian companion, hoping the message might reach her lover. In the corresponding sculpture on Manmatha's column, a male figure dances (fig. 2), his body and face turned directly out and across to the woman and her parrot. He holds his right hand aloft, perhaps ready to receive love's messenger.

Seated below this figure and turned in three-quarter profile is Manmatha, mounted on his gander, his feet in the stirrups, his right arm drawn back to launch a devastating weapon: the piercing arrow of love. Complementing this image of imminent yearning is the figure of a woman on the opposite pillar who lifts a mirror to her face with her left hand as she reaches over her head with her right hand to apply an auspicious mark (pottu) on her brow. Like the woman holding the parrot, hers is a conventional representation, described in treatises and depicted on temples throughout the Indian subcontinent. She is "the maiden holding a mirror" (darpana-sundarī) an auspicious female figure described in an eleventh-century text on temple decoration, where she is said to be beautiful and to give pleasure to people who see her. She is one of the many conventional beauties (sundari $)$ that decorate auspicious buildings and are imbued with meaning in this context. Paired across from an iconographically specific form of Manmatha and integrated into the column of Rati, this figure is polyvalent. She is the conventional type of woman, described in typologies of beautiful and auspicious women, and she is an aspect of Rati, the goddess of love and paradigm of both lover and beloved. As one who holds a mirror, she is a metadiscursive figure, alerting us to the mirroring of the themes and poses of the figures depicted on the two columns.

At the lowest level of the pillar is the figure of a woman who holds on to the tender stem of a banana tree, which curves over her body, echoing its sensuous form. She kicks the banana stem with her right foot, causing it to flower and bear fruit-its fruition is evident in the heavy blossom hanging freely on the right side of the figure. She is śälabhañjikā, an auspicious female form common to Buddhist, Jain, and Hindu temples from ancient times, who with her laugh or the kick of a foot causes a tree to bear fruit. It is an iconography repeated in art and literature, perhaps most famously in the story of the mother of the Buddha, who grasps the fruiting tree as the Buddha is born from her side. At the hall of marriage, this fructive figure is coupled with another opposing image of Manmatha, who dances, his left hand clutching the sugarcane bow, while held aloft in his right hand is a small fruit-ready, it seems, to be launched in play toward his beloved, a fruit for the one who causes fruition. 
This account of the two faces of the Manmatha and Rati columns that face each other suggest a progression from the flirtation of song and dance that attunes one body to another, to the expression of love and desire through the messenger of the parrot. Below, the god of love launches his arrows, while the mirroring Rati adorns her body with signs both auspicious and beautiful. Finally, the fruit of union is portrayed in the physical fruits that both figures bring into being. While one could find such a reading overdetermined, the sensitive reader would no doubt discern the figures' polyvalent potential in the play of literary and visual tropes, symbols, and figures.

The other faces of both pillars retain the themes of pleasure and desire in figures that are both well-known tropes of beauty and love as well as aspects Manmatha and Rati. Those on Manmatha's column include the god in seated and standing positions, holding his sugarcane bow and flower arrow. At the lowest level of the east face, he is an affectionate lover, holding close a woman who cradles his chin in her hand. On the north face, he is a royal figure, a crown on his head, and fine textiles draped over his arm. Rati's pillar also further suggests the theme of the lover: on the north face, female figures are shown holding parrots, the messenger of love and Rati's conveyance and confidant. On the west, women entertain and serve: the middle and upper images show a woman dancing, while the figure on the lowest level is a fly-whisk-bearing attendant. Collectively, the figures show aspects of the paradigmatic lovers. That the figures are meant to do so is reinforced by the separation of gendered depictions: while other pillars depict both female and male figures, these pillars are segregated by gender, save for the single image of a loving couple. The iconic variations on the themes and guises of love, courtly pleasures, and auspicious fecundity are echoed throughout the building, on the exterior and interior, where scenes of battle and images of gods and saints stand cheek by jowl with images of romantic pleasure, sex, and childbearing. Seen in this light, an expansive reading of the figures of Manmatha and Rati places them in the context of the hall of marriage, a place that celebrates auspicious union and the riches and pleasures that follow.

The density of ornament upon every surface of the marriage hall, from the rooftop carvings to the massive pillars atop the narrative bands of the building's plinth, overwhelm any ambition to identify each and every detail, figure, or story. Enjoyment of the sculptor's skilled work and his own loving attention to detail and ornament requires careful, slow, and patient looking on the part of the viewer. The fine details of the figures' costume, the curls of the goose's tail, or the design of his bridle encourage the observer to linger. At the same time, to take in the entirety, to consider the ways in which the particular relates to the whole, requires a different mode of perception. The modes of reading that architecture of this kind invites is perhaps akin to the way one reads an epic. Rarely does one encounter the authoritative text of an epic, or read it cover to cover. Rather, one dips into the story, starting at one place or another, picking out an apt moment or lesson, returning to a favorite episode, or being caught off guard by a detail that 
had escaped notice. Like the palimpsestic texts of the great Indian epics, architectural representation invites multilayered readings, inflected by the season or occasion of their telling. Taking a wider view of the architectural context of the pillars, they may be read in light of the festival function of the marriage hall, at the center of which is the dais on which the god and goddess are placed during the celebration of their union, set within the ordered cosmos, and among their loving devotees.

Reading these sculptures with sensitivity means moving in and then again away; caressing the details, if only through sight; and taking in the whole, if only through intuition. It means considering the beauty of the individual and the individual's relationship to others. Such looking invites us into the microcosm of the work's aesthetic world and propels us into the macrocosmic order in which it participates. Such a sensitive reader would surely have been struck by the desiring arrow of a passionate love.

\section{SIDE OBSERVATION OF A SMALL PORTION \\ OF VARADARAJA TEMPLE \\ Tawfiq Da'adli (Far Reader)}

When someone who has become a professional student of art looks at an unfamiliar work, professional habits usually come to the fore as part of the process of analyzing and understanding its meaning. These include itemizing its elements and putting it in a historical and aesthetic context. An expert on Egon Schiele, for instance, will catalog the laundry hung in front of a house and aim to decipher its semiotics. Another alternative is to just stand in front of a painting or a statue, observe it, and enjoy the moment. Such is often the experience when one happens to wander inside an Indian temple: one takes in the icons and sculptured mythological scenes with pleasure, whether or not one has prior knowledge about their background. When professional habits cease to be relevant, then a route to appreciation and enjoyment becomes visible, even though it was always there, accessible to everyone. The key is to observe the surroundings with an open eye and a steady gaze. Works of art are the products of minds that seek to communicate with whomever is willing to participate in this communication. What follows is an exercise in observation leading to appreciation and enjoyment: observing what, for me, is the unknown but reachable in the temple of Varadaraja, King among Boon-Givers.

The Varadaraja temple contains a colonnade supported by no less than ninetysix pillars. Each "tree" in this stone forest is sculptured in a different pattern, but in the main they include figures of warriors and horse-mounted hunters. In front of this massive army of local and some European soldiers are Manmatha and his wife Rati: they welcome visitors into this ornamental pavilion.

Manmatha and Rati's welcome is meant to confer good fortune and prosperity on those approaching the temple. It is no surprise that this ornamental pavilion is 
used for the annual ceremonial marriage of the god and the goddess. Perhaps the road to prosperity always involves being struck by a love arrow. Indeed, Manmatha is preparing to take a shot: one of his hands holds the bow while the other presses an arrow on the string. Notice that the fingers of his right hand are split sideways in a way that makes the posture look more realistic. As you approach, he is aiming at you, so be prepared: soon the arrow of love will hit you.

Rati and Manmatha ride two massive vehicles, a parrot and a gander, respectively. These winged mounts are the core of their individual shafts; that is, these figures of the gods' vehicles are the bulk of the construction and support the ceiling in addition to the gods themselves. Although they are relatively thick and massive, they do not strike us as such at first blush. Indeed, the rounded breast, thin legs, and feather saddle lend them lightness. Although the birds stand solid and are rooted in the rock, they seem to pierce the space in front of them. They are on the move. Charging forward in a similar manner is the horse to the left of Manmatha. Now what is seen with the eyes joins with what the ear hears, for there is no way to observe its legs, leaping up, without hearing the sounds of the horse's neighing and trotting. The horse has been on the move for quite some time, something we know from the way its lower jaw is hanging down with exhaustion.

Rati, situated closer to us from the perspective of figures 1 and 2, is even more welcoming than Manmatha. Manmatha's leg is bent, and you can see the tenseness in the muscles as the leg presses around the lower part of the gander's breast in full alert. By contrast, Rati's leg seems softer-more flesh than muscle-as it is curved around her parrot's feather saddle. Rati's body is also rounded and curved, especially her breast and hip, and her face is orb-shaped with clear features (wide eyes, bold nose, thick lips) and ornaments (necklace and two rounded earrings). If roundness is what unifies Rati's depiction, being muscular, firm, and erect are Manmatha's characteristics, as can be seen in his elongated hat, powerful thighs, brawny palms, and his thick arrow or cluster of arrows.

Just ahead of this orchestra of round lines, floating figures, and a sweating horse hangs a chain that falls in isolation from the roof. This straight, suspended line, which appears to be falling from the sky, is also carved in stone. It is easy to lose sense of its weight, as the surrounding air dwarfs the links of gray stone. There is more thickness here, but now thick rings appear thin, and the chain ends with the last link attached to a kind of lotus bud, its pointed end facing down, making the line appear even thinner. The tension between the lightness of the line and the mass of the horses and the winged mounts increases the sense of motion.

These Indian-style caryatids, then, both support the ceiling and move the entire temple through space. They do not stand still like the ones at the Acropolis. They are constantly on the move. Motion is key. More specifically, the caryatids are on the move just like almost everything in the typical Indian temple in the Deccan. Vishnu of Three Steps (Trivikrama) is constantly in motion: one leg reaching to conquer heaven, one taking hold of earth, and a third descending down to the 
nether world. He cannot stand still. Other gods, too, have to hurry: they must act quickly to save their devotees from evil powers or from taking their own life (as in the case of the Srisailam temple mentioned later).

The chariot is also on the go, and chariots and temples are closely linked. Temples are chariots, leading the devotees on their journey to the beyond. In addition, most temples in South India have a chariot to carry the gods on their tours and seasonal processions. Sometimes you see a chariot engraved in stone, like the magnificent one I was fortunate to see in front of the Vitthala temple in Hampi: it is carved from stone but appears as if it might move with the slightest breeze. Every detail of decoration is so finely carved, the sense of motion is so present, yet when you near this Hampi chariot, you realize that the movement is seen by the mind's eye, not the body's. If you are distracted and stop seeing the motion that the mind's eye sees, and begin to see only with the body's eye, you get stuck: when seen with the body's eye alone, the chariot will never move, and god will never make his rounds.

On the move is also the temple visitor, the moving observer. I recall my early morning visit to the temple of Srisailam: I remember circling the compound clockwise, walking around the outer walls to observe the richly carved panels. I had to complete the circle to observe the numerous deities. I had to keep moving, and one simple reason was that the crowd, also in constant motion and absorbed in endless recitation, did not allow me to stand still. As a visitor, you can perhaps only come to a halt once you have come full circle. Only then do you begin to realize the nature of your journey.

Srisailam and Varadaraja are large temple compounds in major pilgrimage sites. But even in the smaller shrines inside each temple, you have to keep moving. If you stop, you may overlook a statue of a god, or a small sanctum that awaits your donation-a coconut, or burning incense. Sometimes the deities hide in a remote corner: without circumambulation, you will miss them, and they will miss you. Better to keep moving. The only thing motionless and stable is the lingam, that aniconic image of Shiva at the center of the temple.

Almost no inch of the surface is devoid of motives or figures. The stone leaves behind its hard and frozen nature after being modeled by the chisel. The more the eye wanders with wonder-and this happens naturally, or perhaps it was programed by the artist-the more detail it will see. Dragons supporting the chests of the vehicles, the parrot and the gander, female figures above Manmatha, and more figures above and below the horse in the background. After the body's eye does what it can, the mind's eye will do the rest.

Greek caryatids support the entablature with the classical order composed by the frieze and the cornice. Manmatha and Rati also support an entablature, but in India the order and composition are clearly different. Some sort of order is created by classical vertical and rectangular shapes resting on the deities, but soon the strict lines are replaced with the curves of female figures moving or dancing. At 
first glance, they seem free; at second, you realize they are part of the column and are also supporting the ceiling.

Unlike their Greek or Roman counterparts, these gods and figures are still active and are thus surrounded by modern facilities. In figure 1 we can see electrical wires hanging from the ceiling, and two of them, one white and the other blue, appear almost wrapped around Manmatha's bow. As we have seen, Manmatha has no need for any external power. However, visitors need artificial light to lead them on their path to the holy of holies, especially at night. Hence the scattered electrical wires and the fluorescent lamps that are crudely attached to the fine reliefs and the works of art. But these too inevitably become part of our observation and, indeed, enjoyment. In popular temples, prayers pulsate with red and orange fluorescent lights. At night you can see the parrot breast with some touches of green flashing from the lighted signs. On the same occasions, you can hear the different gods speaking in some soap opera playing on plasma screens, hanging in the different parts of the temple.

Our brief glimpse of a small portion of the temple's welcome façade is as overwhelming to the senses as it is lasting to the mind and the heart, maybe even the soul. Two stone wheels that threaten to start rolling impose themselves in your line of vision. Then you realize that those wheels are mounted by two figures who seem to be comfortable with the ride. As you observe more and enjoy more, you begin to realize that those figures are Love and Desire embodied. One is the object of male desire; the other is shooting love arrows like Cupid.

Unfortunately, as we are observing the whole moving scene from the side, Love and Desire are passing in front of us-there's little chance we can keep up with them. And at the end, an invitation to a future beginning is heard: better that you come at the time of the festival. 